\title{
Lack of FcRn Impairs Natural Killer Cell Development and Functions in the Tumor Microenvironment
}

\section{OPEN ACCESS}

Edited by:

Fabrizio Mattei,

Istituto Superiore di Sanità (ISS), Italy

Reviewed by:

Anahid Jewett,

University of California, Los Angeles,

United States

Dr. Kawaljit Kaur

University of California, Los Angeles,

United States

${ }^{*}$ Correspondence:

Valérie Gouilleux-Gruart

valerie.gouilleux@univ-tours.fr

tThese authors have contributed equally to this work

¥These authors have contributed equally in the design of this project

Specialty section:

This article was submitted to

Cancer Immunity and Immunotherapy,

a section of the journal

Frontiers in Immunology

Received: 08 March 2018 Accepted: 11 September 2018

Published: 28 September 2018

Citation:

Castaneda DC, Dhommée C, Baranek T, Dalloneau E, Lajoie L, Valayer A, Arnoult C, Demattéi M-V,

Fouquenet $D$, Parent $C$,

Heuzé-Vourc'h $N$ and

Gouilleux-Gruart V (2018) Lack of

FCRn Impairs Natural Killer Cell Development and Functions in the

Tumor Microenvironment.

Front. Immunol. 9:2259.

doi: 10.3389/fimmu.2018.02259

\author{
Diana Cadena Castaneda ${ }^{1,2}$, Christine Dhommée ${ }^{1,2+}$, Thomas Baranek ${ }^{1,3+}$, \\ Emilie Dalloneau 1,3, Laurie Lajoie ${ }^{1,2}$, Alexandre Valayer ${ }^{1,3}$, Christophe Arnoult ${ }^{1,2}$, \\ Marie-Véronique Demattéi ${ }^{1,2}$, Delphine Fouquenet ${ }^{1,3}$, Christelle Parent ${ }^{1,3}$, \\ Nathalie Heuzé-Vourc' $h^{1,3 \neq}$ and Valérie Gouilleux-Gruart ${ }^{1,2 \times \neq}$ \\ ${ }^{1}$ Université François Rabelais de Tours, Tours, France, ${ }^{2}$ CNRS, GICC UMR 7292, Tours, France, ${ }^{3}$ INSERM, Centre d'Etude \\ des Pathologies Respiratoires, U1100, Tours, France
}

The neonatal Fc receptor ( $\left.F_{C R n}\right)$ is responsible for the recycling and transcytosis of IgG and albumin. FcRn level was found altered in cancer tissues and implicated in tumor immunosurveillance and neoplastic cell growth. However, the consequences of FcRn down-regulation in the anti-tumor immune response are not fully elucidated. By using the B16F10 experimental lung metastasis model in an FcRn-deficient microenvironment ( $\mathrm{FCRn}^{-/}$- mice), we found lung metastasis associated with an abnormal natural killer (NK) cell phenotype. In FcRn-/- mice, NK cells were immature, as shown by their surface marker profile and their decreased ability to degranulate and synthesize interferon $\gamma$ after chemical and IL-2 or IL-12, IL-15 and IL-18 activation. These new findings support the critical role of FCRn downregulation in the tumor microenvironment in anti-tumor immunity, via NK cell maturation and activation.

Keywords: FcRn, anti-tumor immunity, NK cells, IFN- $\gamma$, CD107a, fcgrt knock-out

\section{INTRODUCTION}

The neonatal $F c$ receptor $(\mathrm{FcRn})$ is a member of the IgG-Fc receptor family comprising type I (e.g., "classical" Fc $\gamma$ Rs) and type II (e.g., non-classical FcR: FcRn, TRIM21) receptors (1-3). The structure, expression and functions of this IgG-Fc receptors have been extensively rewiewed regarding their major role in the regulation of immune responses (4). FcRn is an MHC class I-related molecule consisting of a heavy chain associated with $\beta 2$-microglobulin molecule, wellknown for its role in regulating IgG and albumin homeostasis (5). Indeed, FcRn-dependent IgG and albumin recycling leads to an extended half -life of these two molecules $(6,7)$. FcRn is also a main actor in the biodistribution of IgG and albumin throughout the body, via transcytosis $(3,8)$. Accordingly, FcRn expression is ubiquitous within organs and tissues, with high expression in endothelial and epithelial cells (9). It is also expressed by hematopoietic cells, in particular macrophages/monocytes and dendritic cells (DCs) (10). The expression of FcRn in antigenpresenting cells is connected to its implication in the humoral immune response, via an immune complex presentation (11).

Besides these functions, FcRn was recently found an important player in anti-tumor immunity. First, FcRn in immune cells was shown to be critical for the activation of tumor-reactive $\mathrm{CD}^{+}{ }^{+} \mathrm{T}$ cells in colorectal cancer (12). The density of FcRn-expressed DCs was correlated with $\mathrm{CD}^{+} \mathrm{T}$-cell number and predicted improved prognosis in human colorectal carcinoma. Second, we reported FcRn mRNA and protein levels in both lung cancerous tissue and non-cancerous tissue 
associated with favorable prognosis in non-small cell lung cancer (13). Third, studies involving neoplastic cells expressing different levels of FcRn showed that FcRn-mediated recycling of albumin reduced tumor cell growth and proliferation (14).

Because FcRn may shape additional anti-tumor properties, here we further investigated the consequences of its downregulation. We used the B16F10 experimental lung metastasis model $(15,16)$ in an FcRn-depleted environment $\left(\mathrm{FcRn}^{-/-}\right.$mice) and compared the different cellular components of the anti-tumor immune response in wild-type (WT) and $\mathrm{FcRn}^{-/}$mice. We explored natural killer (NK) cells as relaying FcRn-dependent anti-tumor immunity. These cells are important in the host and therapy-induced immune response against cancer $(17,18)$ and their efficacy in vivo is compromised by suppressive signals delivered by tumor or tumor-associated cells $(19,20)$.

\section{MATERIALS AND METHODS}

\section{Cell Line}

The murine melanoma cell line B16F10 $\mathrm{Luc}^{+}$was a kind gift from Dr Laurent Gros (Institute of Cancer Research of Montpellier, Montpellier, France). The murine lymphoma cell line YAC1 was purchased from the American Type Culture Collection (ATCC). B16F10 Luc ${ }^{+}$and YAC-1 cells were maintained in RPMI 1640 culture medium (Sigma-Aldrich) supplemented with $10 \%$ heat-inactivated FBS (Lonza), 2 mM L-glutamine, $100 \mathrm{U} / \mathrm{ml}$ penicillin and $100 \mu \mathrm{g} / \mathrm{ml}$ streptomycin (Sigma-Aldrich) referred as complete medium.

\section{B16F10 Experimental Lung Metastasis Model}

WT C57BL/6J mice were obtained from Charles River Laboratories. $\mathrm{FcRn}{ }^{-/}$C57BL/6J mice, deficient in fcgrt gene (B6.129X1-Fcgrt tm1 Dcr/DcrJ $\left(\mathrm{fcgrt}^{-/-}\right)$], were originally purchased from The Jackson Laboratory. A targeting vector was designed to replace 1,588 nucleotide fragments (encoding the promoter sequence $5^{\prime}$ end of the transcriptional start site, exon 1, intron 2, and most of exon 2) with a PGK-NeoR cassette. The vector was electroporated into $129 \mathrm{X} 1 / \mathrm{SvJ}$-derived ESV/J-1182 embryonic stem (ES) cells. Correctly targeted ES cells were injected into recipient $\mathrm{C} 57 \mathrm{BL} / 6 \mathrm{~J}$ blastocysts. The resulting chimeric animals were crossed to $\mathrm{C} 57 \mathrm{BL} / 6 \mathrm{~J}$ mice. The mice were then backcrossed to $\mathrm{C} 57 \mathrm{BL} / 6 \mathrm{~J}$ for 11 generations. All mice were maintained in a dedicated pathogen-free environment in our animal facility and were used at age 7-12 weeks. All animal studies were performed according to French national regulations (EC directive 86/609/CEE, French decree no. 87-848) after approval was received from the Committee on the Ethics of Animal Experiments of the Val-de-Loire, CEEA VdL (referral no. 2015070117414040).

Syngeneic experimental lung metastases were induced by intravenously injecting $10^{5} \mathrm{~B} 16 \mathrm{~F} 10 \mathrm{Luc}^{+}$melanoma cells in 100 $\mu l$ RPMI 1640 medium in the tail vein of WT and FcRn ${ }^{-/-}$ mice. The cells colonized lungs and formed well-defined black melanocytic nodules in the lung $(15,21)$. After 18 days, mice were euthanized. Lungs and spleens were harvested for further analysis. Lungs were scored for number of tumor nodules.

\section{Cell Preparation for Flow Cytometry}

Lungs were dissociated into single-cell suspensions by combining mechanical dissociation (gentleMACS Dissociators, Miltenyi) with enzymatic degradation of the extracellular matrix. The enzymatic degradation involved use of a digestion buffer: RPMI 1640 containing 5\% FBS, $125 \mu \mathrm{g} / \mathrm{ml}$ Liberase LT (Roche Diagnostics) and $100 \mu \mathrm{g} / \mathrm{ml}$ DNAse corresponding to $200 \mathrm{Kuntz}$ units/ml DNAse (Roche Diagnostics). Spleens were flushed with a $25 \mathrm{G}$ needle and syringe containing the digestion buffer, then incubated for $30 \mathrm{~min}$ at $37^{\circ} \mathrm{C}$. Bone-marrow cells were isolated from the femur and tibia by flushing with a $25 \mathrm{G}$ needle and syringe containing $1 \mathrm{X}$ PBS. Red blood cells in the resulting cell suspensions were lysed by using an ammonium chloride buffer, then filtered (70 $\mu \mathrm{m}$, MACS SmartStrainers) and resuspended at $10^{7}$ cells $/ \mathrm{ml}$ in $1 \mathrm{X}$ PBS containing $5 \%$ FBS and $2 \mathrm{mM}$ EDTA.

\section{Murine NK-Cell Isolation And ex vivo Expansion and Stimulation}

NK cells were isolated from pooled spleens of WT or FcRn ${ }^{-/-}$ mice by negative selection with magnetic Microbeads (NK cell isolation kit II, Miltenyi). NK-cell purity was $>90 \%$. NK cells were expanded in RPMI 1640 complete medium supplemented with 5,000 U/ml rhIL2 (PreproTech) for 4 days. For the cell growth and mortality analyses, cells were counted daily using a cell counting chamber (Malassez). Cell surfacemobilized CD107a and intracellular IFN- $\gamma$ levels were measured as described (22) after 4-h stimulation with phorbol 12-myristate 13 -acetate (PMA, $100 \mathrm{ng} / \mathrm{mL}$ ) and $500 \mathrm{ng} / \mathrm{mL}$ ionomycin calcium (Sigma-Aldrich) at $37^{\circ} \mathrm{C}$ in $5 \% \mathrm{CO}_{2}$. Next, $10^{5}$ freshly isolated NK cells were added per well with $5 \mu \mathrm{l}(0.5 \mathrm{mg} / \mathrm{ml})$ anti-CD107a (clone 1D4B, FITC, Becton Dickinson [BD]) and $1 \mu \mathrm{g} / 10^{6}$ cells of brefeldin A (GolgiPlug, BD). At the end of incubation, cells were washed with $1 \mathrm{X}$ PBS containing 5\% FBS and 2 mM EDTA. Then, NK cells were treated with an Fc block (anti-CD32/CD16 in the form of $2.4 \mathrm{G} 2$ hybridoma culture supernatant) to inhibit non-specific antibody binding for $20 \mathrm{~min}$ and stained for surface NK-cell markers: NK1,1 (clone PK136, APC, BD), NKp46 (clone 29A1.4, Pe, BD), CD27 (clone LG.3A10, PeCy7, BD) and CD11b (clone M1/70, PerCPCys5.5, BD) for $30 \mathrm{~min}$. Samples were fixed and permeabilized according to the manufacturer's instructions (BD) and stained for intracellular IFN- $\gamma$ (clone XMG1.2, APC$\mathrm{H} 7, \mathrm{BD})$ for an additional $30 \mathrm{~min}$. After washing, cells were analyzed by flow cytometry. For cytokine induced cell surfacemobilized CD107a and intracellular IFN- $\gamma$ production, $2 \times$ $10^{6}-5 \times 10^{6}$ freshly isolated splenocytes were seeded in RMPI 1640 complete medium supplemented or not with 5,000 U/ml rhIL2 or $5 \mathrm{ng} / \mathrm{ml}$ rhIL12 (MBL), $50 \mathrm{ng} / \mathrm{ml}$ rhIL15 (Miltenyi) and $10 \mathrm{ng} / \mathrm{ml} \mathrm{rhIL} 18$ (MBL) for 4 - $\mathrm{h}$ in the presence of brefeldin A and anti-CD107a. After incubation, the cells were additionally stained for CD3, NKp46, NK1.1 and IFN- $\gamma$ flow cytometry analysis.

\section{Murine NK-Cell Cytotoxicity Assay}

For in vitro cytotoxicity assays, isolated NK cells were maintained overnight in RPMI 1640 complete medium supplemented with $50 \mathrm{U} / \mathrm{ml} \mathrm{rhIL2}$ and mixed at indicated effector: target ratios 
(10:1, 5:1 and 1:1) with carboxyfluorescein diacetate succinimidyl ester (CFSE, TonboBio) labeled target YAC-1 cells as previously described $(23,24)$. After 4 -h of incubation at $37^{\circ} \mathrm{C}$, the specific target cell lysis was assessed by flow cytometry (23).

\section{Flow Cytometry}

Single-cell suspension prepared from mouse lungs and spleens were analyzed by flow cytometry (MACSQuant Analyzer 10, Miltenyi). After adding Fc blocking 2.4G2 hybridoma supernatant, cells were stained with mixtures of monoclonal antibodies at the optimal concentration determined in our laboratory and designed to distinguish leukocytes. Mix 1, for dendritic cells, neutrophils and macrophage/monocytes: CD45 (clone 30-F11, APC-H7, BD), CD11c (clone N418 APC, BD), CD11b (PErCPCys5.5, BD), Ly6G (clone 1A8, FITC, eBioscience [eBio]), Ly6C (clone HK1.4, PeCy7, eBio), and F4/80 (clone BM8, V450, BD). Mix 2, for B and T lymphocytes: CD45, CD19 and B220 (clone RA3-6B2, APC, BD), CD3 and TCR (clone H57-597, V450, BD), CD8 (clone 53-6.7, PerCPCys5.5, $\mathrm{BD}$ ) and CD4 (clone GK1.5, PeCy7, eBio). Mix 3, for NK cells: CD45, exclusion of T and B cells (lineage CD3/TCR/CD19/B220, V450), NKp46 (PE, eBio); and for NK maturation, CD27 (APC, $\mathrm{BD})$ and CD11b (PErCPCys5.5, BD). For bone-marrow singlecell suspensions, an exclusive additional mix was used for NK development: CD45, exclusion of $\mathrm{T}$ and $\mathrm{B}$ cells (lineage CD3/TER119/C19/B220, FITC), CD122 (clone TM-beta 1, Pe, eBio), NK1,1 (PerCPCys5.5, BD), NKp46 (V450, BD), CD11b (PeCy7, BD), and CD49b (clone DX5, APC, BD). LIVE/DEAD Fixable Aqua Dead Cell Stain Kit (Invitrogen) was added for excluding nonviable cells in all analyses. Data analysis involved use of Kaluza 1.3 flow cytometry analysis software (Beckman Coulter).

\section{Statistical Analysis}

All results are expressed as median \pm Min to Max, unless specified. Statistical significance was analyzed by two-tailed non-parametric and unpaired Wilcoxon-Mann-Whitney test. $P<0.05$ was considered statistically significant. Statistical analysis involved use of Prism 5 (GraphPad Software, San Diego, CA), where, ns $=$ not significant, ${ }^{*} p \leq 0.05,{ }^{* *} p \leq 0.005$ and ${ }^{* * *} p$ $\leq 0.0001$

\section{RESULTS}

\section{Abnormal Immune Cell Profile Associated With Development of Experimental Lung Metastasis in Mice Lacking FcRn}

To dissect the role of FcRn in anti-tumor immunity, we used the well-characterized syngeneic B16F10 experimental lung metastasis mouse model $(15,16)$. B16F10 cells were intravenously injected in WT and $\mathrm{FcRn}^{-/-} \mathrm{C} 57 \mathrm{BL} / 6$ mice. Macroscopy of lungs revealed a greater number of pulmonary nodules in $\mathrm{FcRn}^{-/-}$than WT mice at 18 days post-implantation (Figure 1). No nodule was detected in other organs under the experimental conditions.

To investigate the immune cell populations in lungs of WT and FcRn ${ }^{-/-}$mice, we used flow cytometry of cell

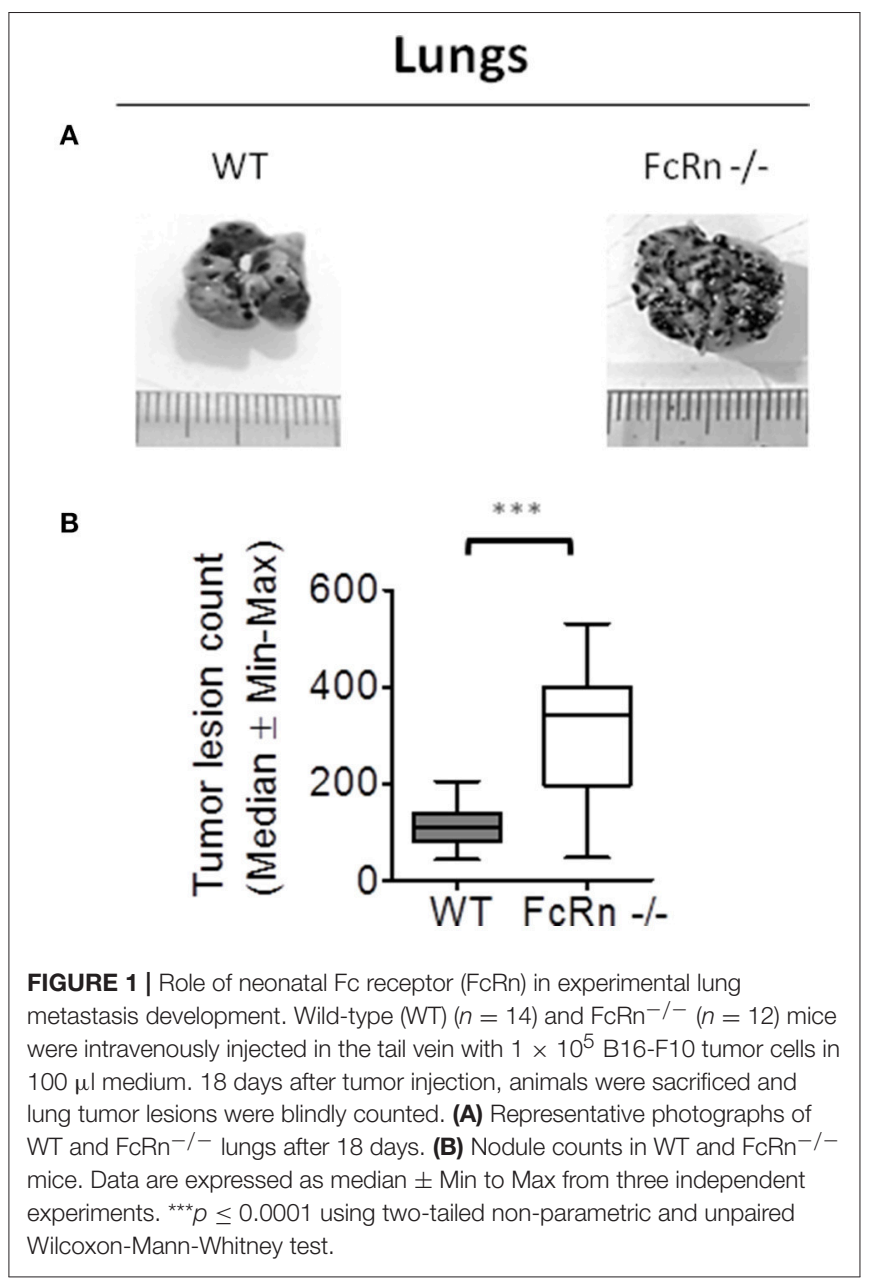

suspensions from fully dissociated lungs to distinguish leukocyte populations (Supplementary Figure S1). The

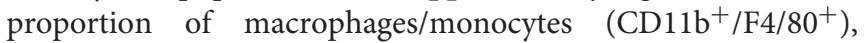
B lymphocytes $\left(\mathrm{CD} 19^{+} / \mathrm{B} 220^{+}\right)$, T lymphocytes $\left(\mathrm{CD}^{+} / \mathrm{TCR}^{+}\right)$ and $\mathrm{CD}^{+} \mathrm{T}$ lymphocytes $\left(\mathrm{CD}^{+} / \mathrm{TCR}^{+} / \mathrm{CD}^{+}\right)$did not differ between $\mathrm{FcRn}^{-/-}$and WT mice (Figures 2B-F), but that of conventional dendritic cells (cDCs: $\left.\mathrm{CD} 11 \mathrm{c}^{+} / \mathrm{CD}_{11 \mathrm{~b}^{+}}\right)$and $\mathrm{CD}^{+} \mathrm{T}$ lymphocytes $\left(\mathrm{CD} 3^{+} / \mathrm{TCR}^{+} / \mathrm{CD}^{+}\right)$was significantly lower in $\mathrm{FcRn}^{-/}$than WT mice (Figures 2A,G). As well, the percentage of neutrophils $\left(\mathrm{CD} 11 \mathrm{~b}^{+} / \mathrm{Ly}^{6} \mathrm{G}^{+}\right)$was significantly higher in $\mathrm{FcRn}^{-/-}$than WT mice (Figure 2C). The proportion of $\mathrm{NK}$ cells $\left(\mathrm{CD} 3^{-} / \mathrm{B} 220^{-} / \mathrm{NKp} 46^{+}\right)$, which do not express FcRn (Supplementary Figure S2), was significantly decreased in $\mathrm{FcRn}^{-/}$mice (Figure 2H). As well, the number of NK cells was altered but not significantly $(p=0.059)$ in $\mathrm{FcRn}^{-/}$mice (Figure 2P). The amount of other cell types was not affected (Figures 2I,J,L-O), except for neutrophils, which were increased in $\mathrm{FcRn}^{-/}$mice (Figure 2K).

Because the lungs are the main primary site of B16F10 nodules after intravenous injection, we explored whether the cell modifications were also detected in other peripheral 


\section{Cell percentage}

A

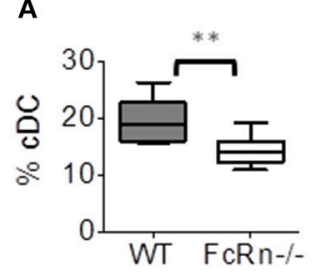

E

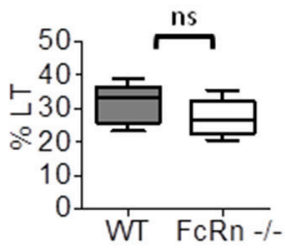

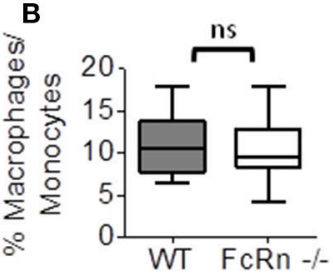

F

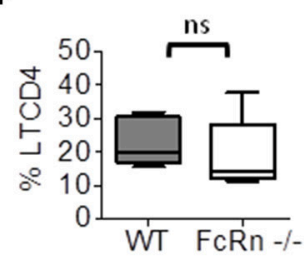

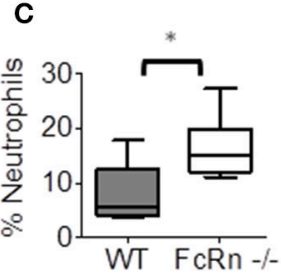

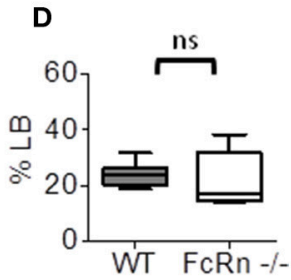

G

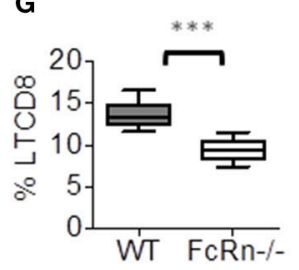

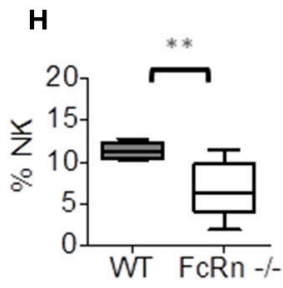

\section{Cell number}

I

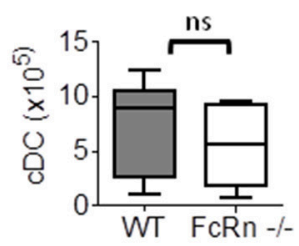

M

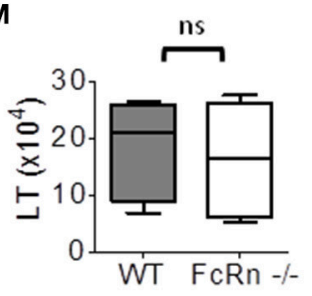

J

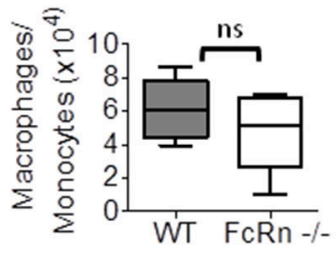

N

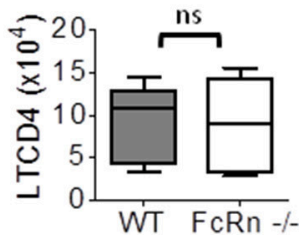

$\mathrm{K}$

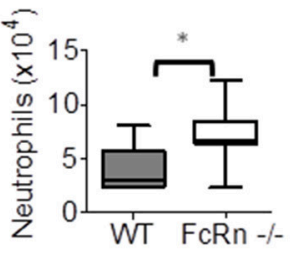

○

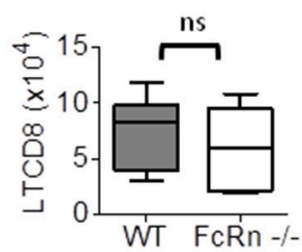

$\mathbf{L}$

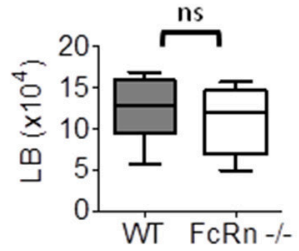

P

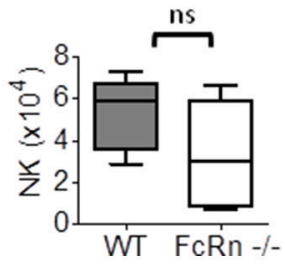

FIGURE 2 | Flow cytometry of leukocytes in lungs of WT $(n=8)$ and FcRn ${ }^{-1-}(n=8)$ mice injected, in the tail vein, with $1 \times 10^{5}$ B16-F10 tumor cells in $100 \mu$ l medium. Lungs were excised and dissociated by combining mechanical dissociation with enzymatic degradation of the extracellular matrix to obtain a single-cell suspension and cells were resuspended at $10^{7}$ cells $/ \mathrm{ml}$ in 1 X PBS containing $5 \%$ FBS and $2 \mathrm{mM}$ EDTA for flow cytometry staining. Results correspond to the proportion (top panel: $\mathbf{A}-\mathbf{H}$ ) and number (bottom panel: $\mathbf{I}-\mathbf{P})$ of $\mathbf{( A , I ) ~ c o n v e n t i o n a l ~ d e n d r i t i c ~ c e l l s , ~ ( B , J ) ~ m a c r o p h a g e s / m o n o c y t e s , ~} \mathbf{( C , K )}$ neutrophils, (D,L) B lymphocytes, (E,M) T lymphocytes, (F,N) CD4 T lymphocytes, (G,O) CD8T lymphocytes, and (H,P) natural killer (NK) cells (See Figure S1 for gating strategy). Data are expressed as median \pm Min to Max from one out of three independent experiments with similar results. ns $=$ not significant, ${ }^{*} p \leq 0.05,{ }^{\star \star} p \leq 0.005$, and ${ }^{\star \star *} p \leq$ 0.0001 using two-tailed non-parametric and unpaired Wilcoxon-Mann-Whitney test.

organs, such as the spleen, where no nodule was detected under our experimental conditions. In the spleen, the percentage and number of macrophages/monocytes (Figures 3B,J) and neutrophils (Figures 3C,K) were significantly greater in $\mathrm{FcRn}^{-/}$than WT mice. There was no difference in percentage and number of B lymphocytes (Figures 3D,L), T lymphocytes (Figures 3E,M) and $\mathrm{CD}^{+} \mathrm{T}$ lymphocytes (Figures 3F,N). The numbers of cDCs, $\mathrm{CD}^{+} \mathrm{T}$ lymphocytes and $\mathrm{NK}$ cells were decreased in $\mathrm{FcRn}^{-/-}$mice (Figures 3I,O,P), with no variation in proportion of these cells (Figures 3A,G,H). Altogether, data obtained in this experimental lung metastasis model are consistent with the implication of $\mathrm{cDCs}, \mathrm{CD}^{+} \mathrm{T}$ lymphocytes and NK cells in tumor development in $\mathrm{FcRn}^{-/-}$mice.

\section{Lack of FcRn Affects NK Cell Maturation in Experimental Lung Metastasis Model}

To gain insight into defective NK cells in an FcRn-depleted microenvironment, we explored NK cell maturation by flow 


\section{Cell percentage}

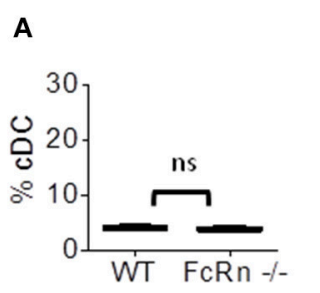

E

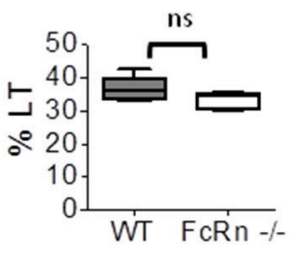

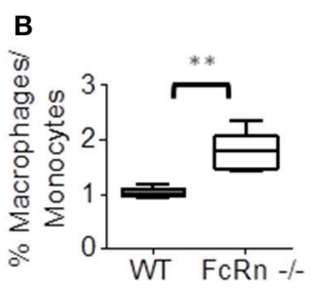

F

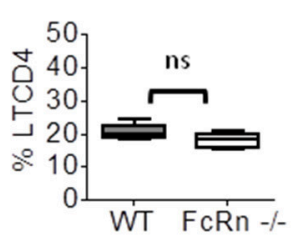

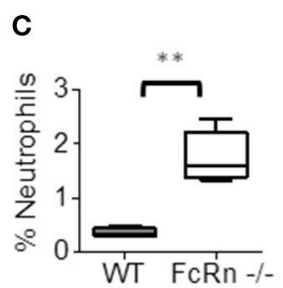

G

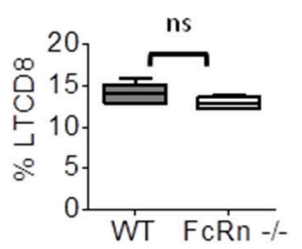

D

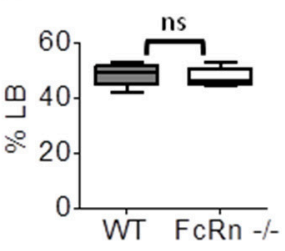

H

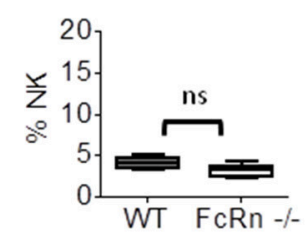

\section{Cell number}

I
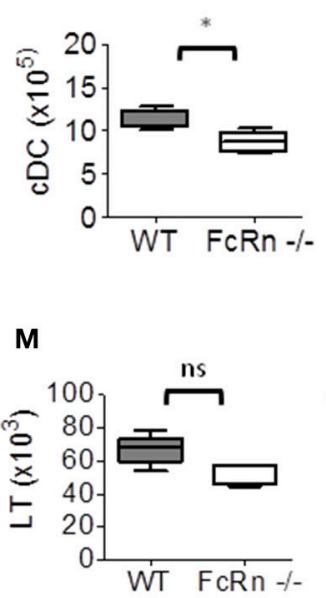

J

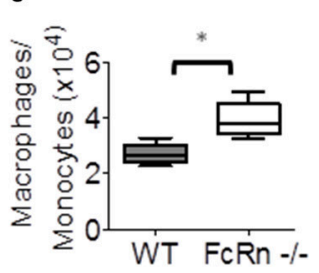

N

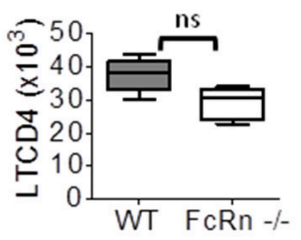

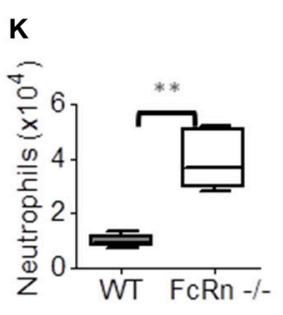

L
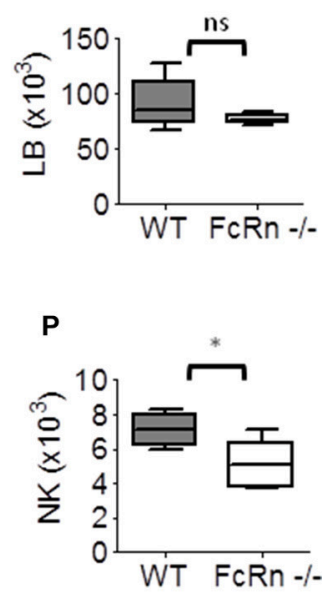

FIGURE 3 | Flow cytometry of leukocytes in the spleen of WT $(n=5)$ and FcRn-/- $(n=5)$ mice injected, in the tail vein, with $1 \times 10^{5}$ B16F10 tumor cells in $100 \mu$ I medium. Spleens were recovered and dissociated by combining mechanical dissociation with enzymatic degradation of the extracellular matrix to obtain a single-cell suspension. Then, cells were resuspended at $10^{7} \mathrm{cell} / \mathrm{ml}$ in 1 X PBS containing 5\% FBS and $2 \mathrm{mM}$ EDTA for flow cytometry staining. Results correspond to the proportion (top panel: $\mathbf{A}-\mathbf{H}$ ) and number (bottom panel: I-P) of (A,I) conventional dendritic cells, (B,J) macrophages/monocytes, $\mathbf{( C , K ) ~ n e u t r o p h i l s , ~} \mathbf{( D , L ) ~ B ~}$ lymphocytes, (E,M) T lymphocytes, (F,N) CD4 T lymphocytes, (G,O) CD8 T lymphocytes, and $\mathbf{( H , P ) ~ N K ~ c e l l s . ~ D a t a ~ a r e ~ e x p r e s s e d ~ a s ~ m e d i a n ~} \pm$ Min to Max from one of two independent experiments with similar results. $\mathrm{ns}=$ not significant, ${ }^{*} p \leq 0.05$ and ${ }^{* *} p \leq 0.005$ using two-tailed non-parametric and unpaired Wilcoxon-Mann-Whitney test.

cytometry on cell suspensions from lungs and spleen of mice implanted with B16 cells. We distinguished the different stages of NK-cell maturation as previously described under physiological conditions $(25,26)$. In peripheral organs, mouse NK-cell maturation proceeds through four stages based on

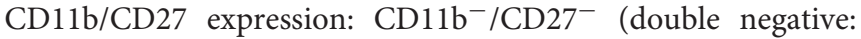
$\mathrm{DN}), \mathrm{CD}_{11 \mathrm{~b}}-/ \mathrm{CD} 27^{+}\left(\mathrm{CD} 11 \mathrm{~b}^{-}\right), \mathrm{CD}_{11 \mathrm{~b}}{ }^{+} / \mathrm{CD} 27^{+}$(double positive: DP), and $\mathrm{CD}_{11 \mathrm{~b}}{ }^{+} / \mathrm{CD} 27^{-}\left(\mathrm{CD} 27^{-}\right)$. We analyzed these different NK subtypes in lungs and spleen of mice (Supplementary Figure S3). In lungs, the proportion of DN,
$\mathrm{CD}_{11 b^{-}}$and DP NK cells was significantly greater in $\mathrm{FcRn}^{-/-}$ than WT mice, whereas that of CD27 ${ }^{-}$NK cells, the more mature NK stage, was significantly decreased (Figure 4A). The sum of

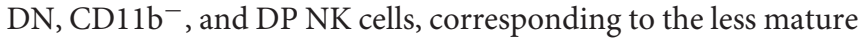
cells, was 31.2 and $21.1 \%$ in $\mathrm{FcRn}^{-/-}$and WT mice, respectively. Similarly, in spleen, the proportion of less mature cells DN NK cells but not CD11b ${ }^{-}$and DP NK cells was greater in $\mathrm{FcRn}^{-/-}$ than WT mice. The proportion of $\mathrm{CD} 27^{-}$NK cells was lower in $\mathrm{FcRn}^{-/-}$than WT mice (Figure 4B). These results reveal less mature NK cells in FcRn-deficient than WT mice in the B16F10 

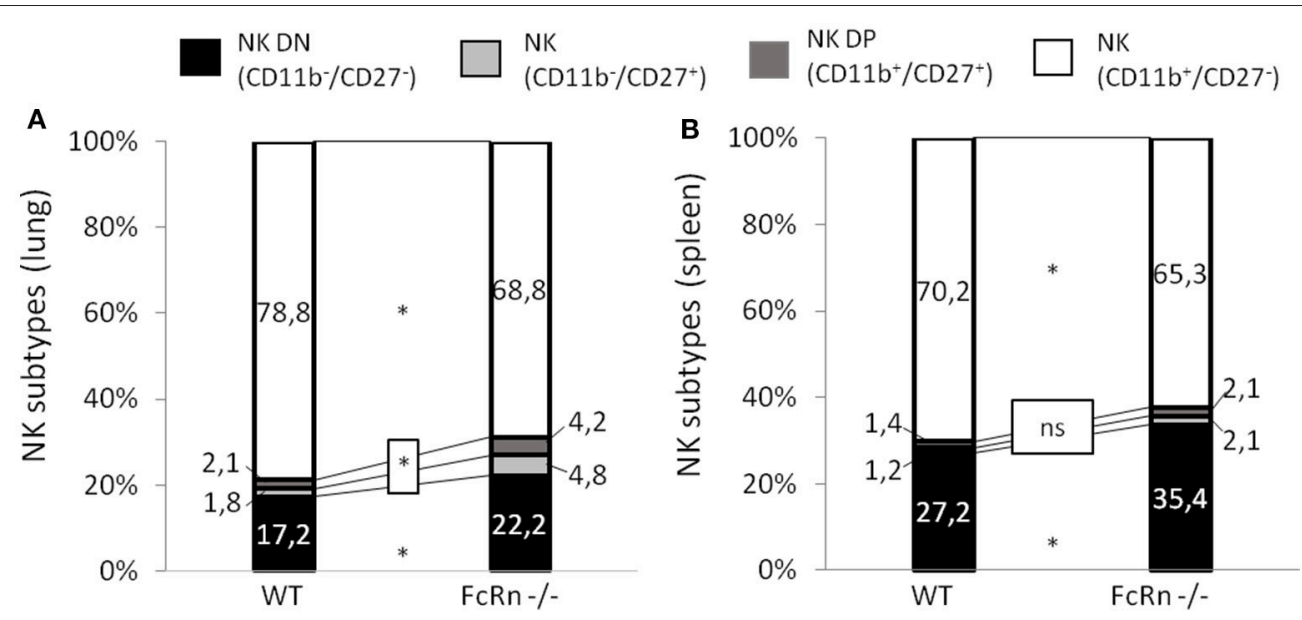

FIGURE 4 | Flow cytometry of NK subtypes based on CD11b and CD27 markers in (A) lungs and (B) spleen from WT $(n=10)$ and FcRn ${ }^{-/-}(n=10)$ mice injected, in the tail vein, with $1 \times 10^{5}$ B16F10 cells in $100 \mu \mathrm{l}$ medium. Lungs and spleen were collected from euthanized animals and dissociated by combining mechanical dissociation with enzymatic degradation of the extracellular matrix to obtain a single-cell suspension. Then, cells were resuspended at $10^{7}$ cells/ml in $1 X$ PBS containing 5\% FBS and $2 \mathrm{mM}$ EDTA for flow cytometry staining. Histograms represent the sum of the percentage of CD11 $\mathrm{b}^{-} / \mathrm{CD}^{2} 7^{-}, \mathrm{CD} 11 \mathrm{~b}^{-} / \mathrm{CD} 7^{+}\left(\mathrm{CD} 11 \mathrm{~b}^{-}\right)$, $\mathrm{CD} 11 \mathrm{~b}^{+} / \mathrm{CD} 27^{+}$, and $\mathrm{CD} 11 \mathrm{~b}^{+} / \mathrm{CD} 27^{-} \mathrm{NK}$ cell subtypes in WT and $\mathrm{FCRn}{ }^{-/}-$mice. Data are means from two independent experiments. ns $=$not significant, ${ }^{*} p \leq 0.05$ using two-tailed non-parametric and unpaired Wilcoxon-Mann-Whitney test.

lung metastasis model, with a more pronounced effect in the lungs.

\section{NK Cell Development/Maturation Is Impaired in FcRn-/- Naive Mice}

To establish whether the defective NK cell maturation was consecutive to B16F10 cell injection or pre-existed in $\mathrm{FcRn}^{-/}$ mice, we phenotyped leukocytes by flow cytometry in naive mice (Supplementary Figures S4, S5) and focused on NK-cell sub-populations. First, the proportion of NK cells in lungs was significantly lower in $\mathrm{FcRn}^{-/-}$than WT mice (Figure 5A), with no difference in spleen (Figure 5B). Second, phenotype analysis of NK cells revealed an organ-specific NK subtype distribution previously described $(27,28)$ corresponding to an increased NK DP population in lungs vs. spleen in both $\mathrm{WT}$ and $\mathrm{FcRn}^{-/-}$mice (Figures 5C,D). Third, the proportion of DN and CD11b- $\mathrm{NK}$ cells, corresponding to more immature cells, was greater in lungs and spleen of $\mathrm{FcRn}^{-/-}$than WT mice (31.8 vs. $18.8 \%$ in lungs and 51.7 vs. $39.9 \%$ spleen). Altogether, these results suggest that defective NK cell development/maturation was already present in naive $\mathrm{FcRn}^{-/-}$mice.

To further investigate the origin of the impaired NK cell maturation in an FcRn-depleted environment, we compared NK-cell development in bone marrow of $\mathrm{FcRn}^{-/-}$and WT mice. To distinguish the different stages of NK cell development in bone marrow, we used specific markers as previously described (29). The global level of NK cell precursors in bone marrow did not differ between $\mathrm{FcRn}^{-/-}$and WT mice, as characterized by CD122 expression, also known as interleukin$2 \mathrm{R} \beta$ (Figure 6A). In contrast, the following stages of NK-cell development were altered. The proportion of NK cells in stage $1\left(\mathrm{CD} 122^{+} / \mathrm{NK} .1^{-} / \mathrm{NKp} 6^{-}\right)$was increased in $\mathrm{FcRn}{ }^{-/-}$mice and that of NK cells in stages 3, 4, and 5 was decreased as compared with WT mice (Figures 6B,C). Our results clearly indicate significantly impaired NK cell development in $\mathrm{FcRn}^{-/-}$ mice.

\section{Defective Functions of NK Cells From FCRn $^{-/-}$Mice}

We analyzed the ability of splenic NK cells from $\mathrm{FcRn}^{-/}$and WT naive mice to produce IFN- $\gamma$ and degranulate, which are major functions of $\mathrm{NK}$ cells. For this, we measured de novo IFN- $\gamma$ production by intracellular staining of NK cells and NK cell degranulation by surface mobilization of CD107a, after exogenous stimulation with PMA/ionomycine and cytokines (IL2 or IL-12, IL-15 and IL-18). Overall, NK cells from FcRn ${ }^{-/}$mice produced less IFN- $\gamma$ (Figures 7A,C) and expressed less CD107a on their surface (Figures 7B,D) than those from WT mice in all conditions. To gain insight into $\mathrm{NK}$ function in $\mathrm{FcRn}^{-/}$mice, we assessed NK cell cytotoxicity against YAC-1 cells in basal condition as described by Mizutani et al. (23). Although NK cells from $\mathrm{FcRn}^{-/-}$animals had a significant lower expression of CD107a compared to WT mice (Figure 7D), there was no significant difference in NK cytoxicity against YAC-1 cells (Figure 7E). This result suggests that NK cells from an FcRn ${ }^{-/-}$ deprived microenvironment displayed similar "basal" cytotoxic properties when they are unstimulated. Additionally, we found that NK cells from $\mathrm{FcRn}^{-/}$and WT naive animals proliferated identically (Figure 7F), but died more in the presence of IL-2 $5,000 \mathrm{U} / \mathrm{mL}$ (Figure 7G). Altogether, our results indicate that NK activation by cytokines is impaired in $\mathrm{FcRn}^{-/-}$naive mice.

\section{DISCUSSION}

Herein, we confirmed the crucial role of FcRn in the antitumor immune response in the B16F10 model of experimental 
A

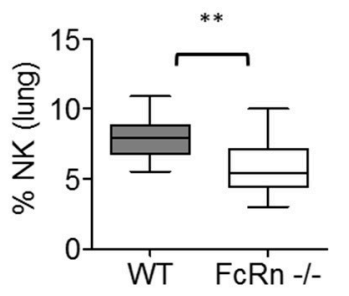

$\square \begin{aligned} & \text { NK DN } \\ & \left(\mathrm{CD} 11 \mathrm{~b} / \mathrm{CD} 27^{-}\right)\end{aligned} \quad \square(\mathrm{NK}$
B

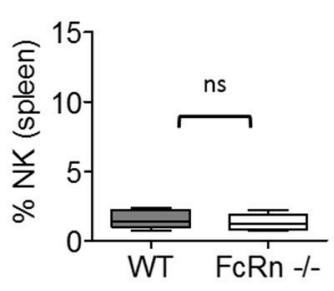

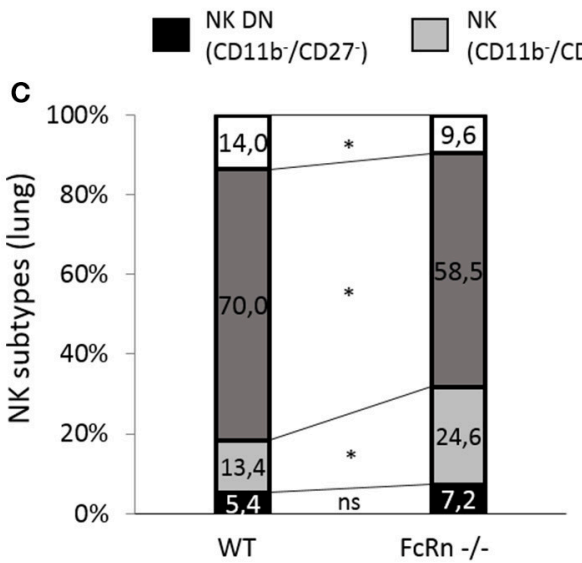

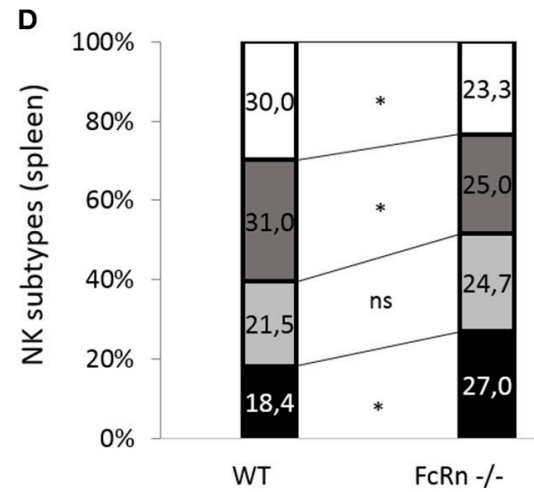

$\mathrm{NK} \mathrm{DP}$
$\left(\mathrm{CD} 11 \mathrm{~b}^{+} / \mathrm{CD} 27^{+}\right)$ $\begin{aligned} & \mathrm{NK} \\ & \left(\mathrm{CD} 11 \mathrm{~b}^{+} / \mathrm{CD} 27^{-}\right)\end{aligned}$

FIGURE 5 | Flow cytometry of NK cell proportion in (A) lungs and (B) spleen from WT $(n=13)$ and FCRn ${ }^{-1-}(n=12)$ naive mice. Data are expressed as median \pm Min to Max from two independent experiments. Flow cytometry of NK subtypes based on CD11b and CD27 markers in (C) lungs and (D) spleen from WT ( $n=5)$ and $\mathrm{FcRn}^{-1-}(n=5)$ naive mice. After euthanasia of naive animals, lungs and spleen were collected and dissociated by combining mechanical dissociation with enzymatic degradation of the extracellular matrix to obtain a single-cell suspension. Then, cells were resuspended at $10^{7}$ cells/ml in 1 X PBS containing $5 \%$ FBS and

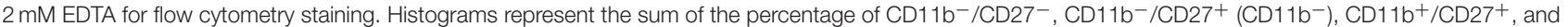

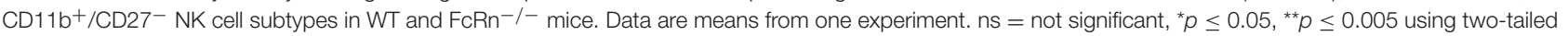
non-parametric and unpaired Wilcoxon-Mann-Whitney test.

\section{WT $\square$ FCRn -/-}
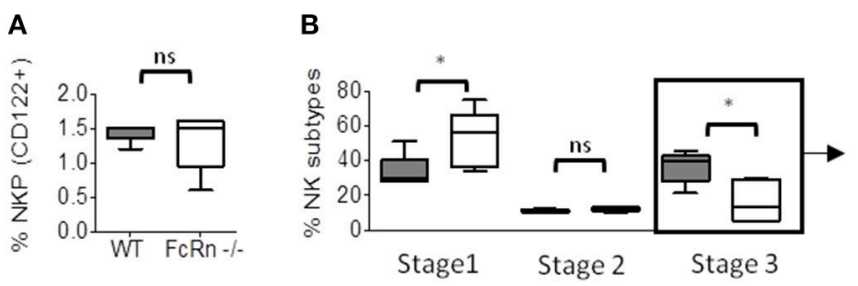

C
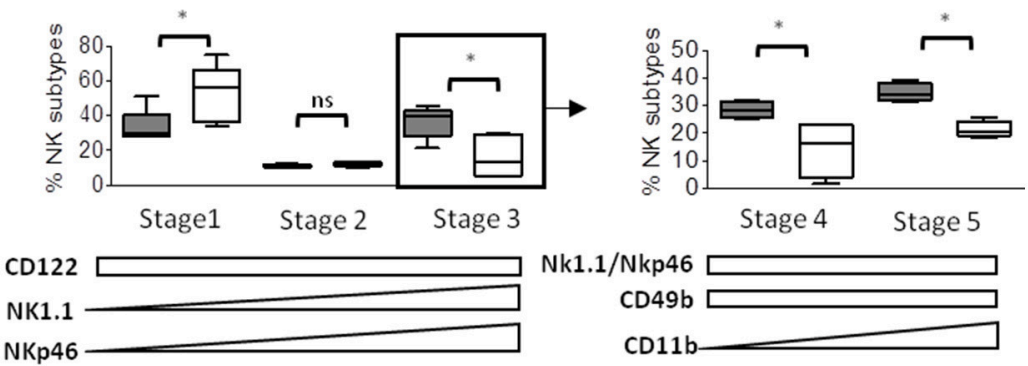

NK development

FIGURE 6 | Flow cytometry of NK cell development in bone marrow of WT $(n=5)$ and FcRn ${ }^{-/-}(n=5)$ naive mice. After euthanasia of naive animals, bone-marrow cells were isolated from the femur and tibia and cells separated by mechanical dissociation. Then, cells were resuspended at $10^{7}$ cells $/ \mathrm{ml}^{\mathrm{m}}$ in $1 \mathrm{X}$ PBS containing $5 \%$ FBS and $2 \mathrm{mM}$ EDTA for flow cytometry staining. The development of NK cells is initiated with the expression of (A) CD122, then three early immature steps [NK precursor (NKP), stage 1 and stage 2] are identified with the expression of (B) CD122, NK1,1 and NKp46. (C) From stage 2, stage 5 and 6 subtypes are characterized by CD49b and CD11b expression. Acquisition of marker during NK cell development is represented schematically by arrows under the graphics. Data are expressed as median \pm Min to Max from one out of two independent experiments with similar results. ns $=$ not significant and ${ }^{*} p \leq 0.05$ using two-tailed non-parametric and unpaired Wilcoxon-Mann-Whitney test. 
WT

FcRn-/-
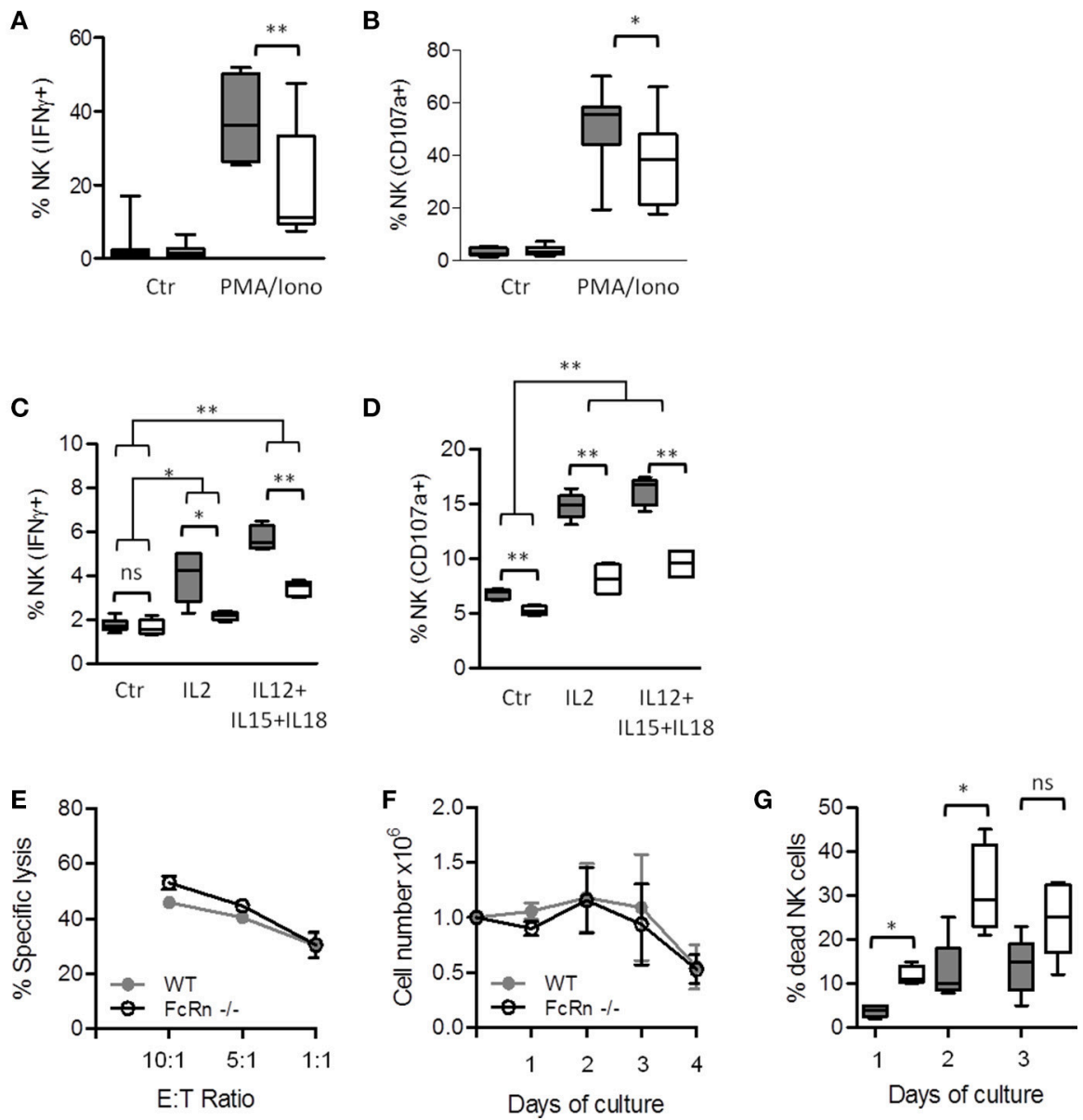

FIGURE 7 | Influence of FcRn on NK cell functions and in vitro expansion. Purified splenic NK cells were analyzed by flow cytometry for (A) the intracellular measurement of IFN- $\gamma$ and (B) the surface expression of the late endosomal marker CD107a, after 4-h incubation at $37^{\circ} \mathrm{C}$ without (Ctr) or with PMA $(100 \mathrm{ng} / \mathrm{mL}) /$ ionomycine $(500 \mathrm{ng} / \mathrm{mL})$. Data are median \pm Min to Max analyzed from eight independent experiments using pooled NK cells from 2 mice. Freshly isolated splenocytes were seeded in RMPI 1640 complete medium supplemented with 5,000 U/ml rhlL2 or with $5 \mathrm{ng} / \mathrm{ml}$ rhlL12, $50 \mathrm{ng} / \mathrm{ml}$ rhlL15, and 10 ng/ml rhlL18 for 4-h (C,D). Within splenocytes, CD3-/NK1.1 ${ }^{+} / \mathrm{NKp}^{-} 6^{+}$cells were analyzed for (C) the intracellular expression of IFN- $\gamma$ and (D) the surface expression of CD107a by flow cytometry. Data are median \pm Min to Max from two independent experiments using pooled spleens from 2 mice. (E) Cytotoxicity assay was performed against CFSE-labeled YAC-1 target cells with different ratios of purified NK cells previously maintained overnight in RPMl 1640 complete medium supplemented with $50 \mathrm{U} / \mathrm{ml}$ of rhIL2 $(n=3)$. The results were expressed as means \pm SEM. (F,G) Purified splenic NK cells were plated in complete medium supplemented with 5,000 U/ml rhIL2. (F) The living cell numbers and (G) the percentage of dead cells were determined daily by manual cell counting using trypan blue in Malassez chamber $(n=3)$. The results were expressed as mean \pm SEM (F) and median \pm Min to Max (G). ns $=$ not significant ${ }^{*} p \leq 0.05$ and ${ }^{* *} p \leq 0.005$ using two-tailed non-parametric and unpaired Wilcoxon-Mann-Whitney test.

lung metastasis in which we clearly show an increase in lung metastasis in an FcRn-depleted environment in mice. Analysis of the immune cells infiltrating the lungs after intravenous injection of B16F10 cells revealed a decreased proportion of $\mathrm{cDCs}$ and CD8 T lymphocytes with lack of FcRn. These results agree with the already assessed function of FcRn-mediated tumor protection driven by DC and CD8 ${ }^{+}$T-cell activities described by Baker et al. (12). However, we identified NK cells as a new and additional cellular component of the FcRn-dependent anti-tumor response.

NK cells are effector lymphoid cells belonging to the innate immune system that can recognize and kill microbial-infected cells and play an important role in the immune surveillance against tumors (30). In this study, mice lacking FcRn showed reduced intratumoral NK-cell infiltration, which may participate in amplified development of B16F10 lung lesions, because NK cells are required for B16F10 tumor rejection $(16,23)$. In $\mathrm{FCRn}^{-/-}$mice, NK cells had an immature phenotype on the whole, as characterized by surface markers (26). The particular cells affected were DP and CD27 ${ }^{-}$NK subtypes, which are able to proliferate under inflammation and exhibit effector functions.

The distribution of the four maturation stages depends on the tissue (31). In our B16F10 experimental lung metastasis 
model, the distribution of the NK cell subtypes was modified in lungs of $\mathrm{FcRn}^{-/-}$mice and in the spleen to a lesser extent. These results suggest that the phenotypic alteration of NK cells is more pronounced in tumor-associated tissues. The alteration may be due to impaired in situ maturation in the tumor lung microenvironment caused by tumor-related soluble factors $(32,33)$. To understand the origin of the NK cell immature phenotype, we evaluated the distribution of NK cell subtypes in $\mathrm{FcRn}^{-/-}$naive mice and found that they also displayed an immature phenotype in lungs as well as spleens. Although NK sub-populations are distributed differently in the spleen and lungs of mice (28) because of distinct homing properties and tissue-specific maturation, their distribution in the different peripheral organs of $\mathrm{FcRn}^{-/-}$mice is unusual. Because NK cells develop from lineage-restricted progenitors in bone marrow, we analyzed NK subpopulations in this compartment. The proportion of NK precursors was higher in $\mathrm{FcRn}^{-/-}$than WT mice, which suggests partial blockade of NKcell development at early steps. This phenomenon confirmed the previously described hindrance effect of tumor growth on NKcell maturation in bone marrow $(17,34)$ that we also observed in our lung experimental metastasis model in WT mice.

Because altered NK-cell maturation would affect the cellular properties of NK cells, we analyzed the ability of NK cells to synthesize IFN- $\gamma$ and mobilize CD107a, which reflects NKcell degranulation/cytotoxic activity. NK cells help eliminate B16F10 tumor cells in the experimental model of lung metastasis (16) and effector molecules, such as perforin and IFN- $\gamma$ play important roles in NK-mediated inhibition of metastasis and tumor growth $(17,35)$. Although, non-activated NK cells from $\mathrm{FcRn}^{-/-}$animals had a significant lower expression of CD107a compared to WT mice, it was not correlated with a reduced cytotoxicity efficacy. Interestingly, $\mathrm{NK}$ cells from $\mathrm{FcRn}^{-/}$mice were less prone to degranulate and synthesize IFN- $\gamma$ after chemical stimulation and (IL-2 or IL-12, IL-15 and IL-18) cytokine activation than NK cells from WT mice. These cytokines are involved in proliferation, differentiation/maturation of NK cells and enhance their effector functions $(36,37)$. Pre-activation of NK cells with IL-2 or IL-12, IL-15 and IL-18 results in the generation of NK cells efficient to target and kill tumor cells $(24,38)$. The lower expression of CD107a and IFN- $\gamma$ synthesis (after IL-2 or IL-12, IL-15, and IL-18 activation) as well as the increased cell death (in the presence of IL-2) in $\mathrm{FcRn}^{-/-} \mathrm{NK}$ cells, support an impaired response of NK cells to cytokines in an $\mathrm{FcRn}^{-/-}$deprived microenvironment. This might be critical to limit the spreading of lung tumor lesions in the B16F10 lung metastasis model. Accordingly, a lower CD107a expression was found in splenic NK cells from $\mathrm{FcRn}^{-/}$animals (compared to WT mice) in the B16F10 model and which persisted after cytokine activation (Supplemental Figure S6).

Once activated, NK cells produce cytokines and chemokines that regulate both the innate and adaptive immune system (39, 40). Because NK cells express no FcRn, the immature phenotype of NK cells might arise via indirect mechanisms due to the absence of FcRn in other cells of the immune system, such as DCs (10). Previous studies described interactions between NK cells and DCs and found a bidirectional crosstalk leading to NK-cell priming by DCs, which in turn induces DC maturation $(41,42)$. Knowing that FcRn-positive DCs are important for shaping the $\mathrm{CD}^{+}$effector T-cell anti-tumor response (12), FcRn might also affect the bidirectional cross-talk between NK cells and DCs. In light of our results showing impaired secretion of IFN- $\gamma$ by NK cells in FcRn ${ }^{-/-}$mice and the important role of IFN- $\gamma$ in DC maturation by NK cells (43), IFN- $\gamma$ might play a role in an FcRndependent cross-talk between NK cells and DC. Following this idea, the defective interleukin-12 level described in $\mathrm{FcRn}^{-/-} \mathrm{DCs}$ (12) may also participate in the impaired NK-cell activation in our model because of its involvement in IFN- $\gamma$ production by $\mathrm{NK}$ cells (41). Other FcRn-expressing cells, such as neutrophils and monocytes/macrophages $(10,44)$ may also be involved in NKcell interactions $(40,45)$. Of note, we found a marked increase in the proportion of neutrophils in $\mathrm{FcRn}^{-/-}$mice as compared with WT mice. Similarly, the proportion of neutrophils was enhanced in the model of anti-TNF antibody immunization in FcRndeficient mice (46) and in other models (47). Previous studies also reported a high number of intratumoral neutrophils associated with the induction and maintenance of tumor angiogenesis $(48,49)$. Moreover, in breast cancer (50) and diverse murine cancer models (51, 52), macrophage/monocyte cells $(53,54)$ and/or neutrophils $(52,55)$ have been implicated in tumor promotion. From this evidence and our results, we cannot rule out a link between neutrophils expressing FcRn (44) and NKcell maturation/activation. Whether this potential interaction occurred via soluble factors, such as cytokines or direct cell contact needs to be investigated. Finally, several cell types present in the hematopoietic niche or secondary lymphoid organs express FcRn. This is the case with stromal cells, endothelial and epithelial cells (44), which may also intervene in NK-cell maturation (36, $40,56,57)$. Further studies are needed to decipher the impact of FcRn-positive cells in the maturation of NK precursors.

For the first time, we described that NK-cell mediated tumor elimination/surveillance is impaired in an FcRn-deficient microenvironment. This could be linked to an abnormal cytokine response which needs further investigations to provide understanding in the involvement of FcRn. In light of our previous results (13) and those from Baker et al. (12), showing FcRn dysregulation in lung and colorectal cancers and associated with an unfavorable outcome, our current findings further support the central role of FcRn in anti-tumor immunity and highlight the interest of targeting FcRn for therapeutic purposes.

\section{AUTHOR CONTRIBUTIONS}

DC performed the research, analyzed, discussed, interpreted data and literature and wrote the manuscript; CD, ED, LL, AV, CA, $\mathrm{M}-\mathrm{VD}, \mathrm{DF}$, and CP contributed to the research and analyzed data; $\mathrm{TB}, \mathrm{NH}-\mathrm{V}$, and VG-G supervised, discussed and verified data analysis and contributed to manuscript preparation.

\section{FUNDING}

This work was supported by a public grant overseen by the French National Research Agency as part of the 
Investissements d'Avenir program (no. ANR-10-LABX-5301 ); the Ligue contre le cancer, Indre et Loire and Finistère committee; the FLUKILLER program from the Région Centre and the PlasTICO program from the Cancéropôle Grand-Ouest.

\section{ACKNOWLEDGMENTS}

We thank Nikita Pallaoro, Cécile Bergua, Thomas Sécher for technical help and Valérie Schnubel, Jérôme Montharu, George Roseau, Chrystophe Aubert, Benjamin Plante, Elodie

\section{REFERENCES}

1. Bruhns P, Jönsson F. Mouse and human FcR effector functions. Immunol Rev. (2015) 268:25-51. doi: 10.1111/imr.12350

2. Caaveiro JMM, Kiyoshi M, Tsumoto K. Structural analysis of Fc/Fc $\gamma \mathrm{R}$ complexes: a blueprint for antibody design. Immunol Rev. (2015) 268:201-21. doi: 10.1111/imr.12365

3. Stapleton NM, Einarsdóttir HK, Stemerding AM, Vidarsson G. The multiple facets of FcRn in immunity. Immunol Rev. (2015) 268:253-68. doi: 10.1111/imr.12331

4. Pincetic A, Bournazos S, DiLillo DJ, Maamary J, Wang TT, Dahan R, et al. Type I and type II Fc receptors regulate innate and adaptive immunity. Nat Immunol. (2014) 15:707-16. doi: 10.1038/ni.2939

5. Roopenian DC, Akilesh S. FcRn: the neonatal Fc receptor comes of age. Nat Rev Immunol. (2007) 7:715-25. doi: 10.1038/nri2155

6. Chaudhury C, Mehnaz S, Robinson JM, Hayton WL, Pearl DK, Roopenian DC, et al. The major histocompatibility complex-related Fc receptor for IgG (FcRn) binds albumin and prolongs its lifespan. J Exp Med. (2003) 197:315-22. doi: 10.1084 /jem. 20021829

7. Ghetie V, Ward ES. Multiple roles for the major histocompatibility complex class I-related receptor FcRn. Annu Rev Immunol. (2000) 18:739-66. doi: 10.1146/annurev.immunol.18.1.739

8. Ramalingam TS, Detmer SA, Martin WL, Bjorkman PJ. IgG transcytosis and recycling by FCRn expressed in MDCK cells reveals ligand-induced redistribution. EMBO J. (2002) 21:590-601. doi: 10.1093/emboj/21.4.590

9. Latvala S, Jacobsen B, Otteneder MB, Herrmann A, Kronenberg S. Distribution of FcRn across species and tissues. J Histochem Cytochem. (2017) 65:321-33. doi: 10.1369/0022155417705095

10. Zhu X, Meng G, Dickinson BL, Li X, Mizoguchi E, Miao L, et al. MHC class I-related neonatal Fc receptor for IgG is functionally expressed in monocytes, intestinal macrophages, and dendritic cells. J Immunol. (2001) 166:3266-76. doi: 10.4049/jimmunol.166.5.3266

11. Baker K, Rath T, Pyzik M, Blumberg RS. The role of FcRn in antigen presentation. Front Immunol. (2014) 5:408. doi: 10.3389/fimmu.2014.00408

12. Baker K, Rath $\mathrm{T}$, Flak MB, Arthur JC, Chen Z, Glickman JN, et al. Neonatal Fc receptor expression in dendritic cells mediates protective immunity against colorectal cancer. Immunity (2013) 39:1095-107. doi: 10.1016/j.immuni.2013.11.003

13. Dalloneau E, Baroukh N, Mavridis K, Maillet A, Gueugnon F, Courty Y, et al. Downregulation of the neonatal Fc receptor expression in non-small cell lung cancer tissue is associated with a poor prognosis. Oncotarget (2016) 7:54415-29. doi: 10.18632/oncotarget.10074

14. Swiercz R, Mo M, Khare P, Schneider Z, Ober RJ, Ward ES. Loss of expression of the recycling receptor, FcRn, promotes tumor cell growth by increasing albumin consumption. Oncotarget (2016) 8:3528-41. doi: 10.18632/oncotarget.13869

15. Fidler IJ, Fidler J. Biological behavior of malignant melanoma cells correlated to their survival in vivo. Cancer Res. (1975) 35:218-24.

16. Grundy MA, Zhang T, Sentman CL. NK cells rapidly remove B16F10 tumor cells in a perforin and interferon-gamma independent manner in vivo. Cancer Immunol Immunother. (2007) 56:1153-61. doi: 10.1007/s00262-006-0264-1
Theyssandier and Michèle De Monte for assistance with the animal facility in our laboratory. We also thank the cellsorting flow facility of the technical platform of François Rabelais University, Tours. English was edited by L.L. Smales (BioMedEditing).

\section{SUPPLEMENTARY MATERIAL}

The Supplementary Material for this article can be found online at: https://www.frontiersin.org/articles/10.3389/fimmu. 2018.02259/full\#supplementary-material

17. Langers I, Renoux VM, Thiry M, Delvenne PJN. Natural killer cells: role in local tumor growth and metastasis. Biol Targets Ther. (2012) 6:73-82. doi: 10.2147/BTT.S23976

18. Chester C, Fritsch K, Kohrt HE. Natural killer cell immunomodulation: targeting activating, inhibitory, and co-stimulatory receptor signaling for cancer immunotherapy. Front Immunol. (2015) 6:601. doi: 10.3389/fimmu.2015.00601

19. Jewett A, Tseng HC. Tumor induced inactivation of natural killer cell cytotoxic function; implication in growth, expansion and differentiation of cancer stem cells. J Cancer (2011) 2:443-57. doi: 10.7150/jca.2.443

20. Sabry M, Lowdell MW. Tumor-primed NK cells: waiting for the green light. Front Immunol. (2013) 4:408. doi: 10.3389/fimmu.2013.00408

21. Overwijk WW, Restifo NP. B16 as a mouse model for human melanoma. Curr Protoc Immunol. (2001) Chapter 20:Unit 20.1. doi: 10.1002/0471142735.im2001s39.B16

22. Lajoie L, Congy-Jolivet N, Bolzec A, Gouilleux-Gruart V, Sicard E, Sung HC, et al. ADAM17-mediated shedding of Fc $\gamma$ RIIIA on human NK cells: identification of the cleavage site and relationship with activation. J Immunol. (2014) 192:741-51. doi: 10.4049/jimmunol.1301024

23. Mizutani T, Neugebauer N, Putz EM, Moritz N, Simma O, Zebedin-Brandl E, et al. Conditional IFNAR1 ablation reveals distinct requirements of Type I IFN signaling for NK cell maturation and tumor surveillance. Oncoimmunology (2012) 1:1027-37. doi: 10.4161/onci.21284

24. Witalisz-Siepracka A, Gotthardt D, Prchal-Murphy M, Didara Z, Menzl I, Prinz D, et al. NK cell-specific CDK8 deletion enhances antitumor responses. Cancer Immunol Res. (2018) 6:458-66. doi: 10.1158/2326-6066.CIR-17 $-0183$

25. Huntington ND, Vosshenrich CAJ, Di Santo JP. Developmental pathways that generate natural-killer-cell diversity in mice and humans. Nat Rev Immunol. (2007) 7:703-14. doi: 10.1038/nri2154

26. Chiossone L, Chaix J, Fuseri N, Roth C, Vivier E, Walzer T. Maturation of mouse NK cells is a 4-stage developmental program. Blood (2009) 113:548896. doi: 10.1016/j.clim.2010.03.147

27. Bozzano F, Marras F, De Maria A. Natural killer cell development and maturation revisited: possible implications of a novel distinct Lin$\mathrm{CD}^{2} 4^{+}$DNAM-1brightCXCR4 ${ }^{+}$cell progenitor. Front Immunol. (2017) 8:268. doi: 10.3389/fimmu.2017.00268

28. Shi F-D, Ljunggren H-G, La Cava A, Van Kaer L. Organ-specific features of natural killer cells. Nat Rev Immunol. (2011) 11:658-71. doi: 10.1038/nri3065

29. Baranek T, Morello E, Valayer A, Aimar R-F, Bréa D, Henry C, et al. FHL2 regulates natural killer cell development and activation during Streptococcus pneumoniae infection. Front Immunol. (2017) 8:123. doi: 10.3389/fimmu.2017.00123

30. Morvan MG, Lanier LL. NK cells and cancer: you can teach innate cells new tricks. Nat Rev Cancer (2015) 16:7-19. doi: 10.1038/nrc.2015.5

31. Michel T, Poli A, Domingues O, Mauffray M, Thérésine M, Brons NHC, et al. Mouse lung and spleen natural killer cells have phenotypic and functional differences, in part influenced by macrophages. PLOS ONE (2012) 7:e51230. doi: 10.1371/journal.pone.0051230

32. Hochweller K, Striegler J, Hämmerling GJ, Garbi N. A novel CD11c.DTR transgenic mouse for depletion of dendritic cells reveals their requirement 
for homeostatic proliferation of natural killer cells. Eur J Immunol. (2008) 38:2776-83. doi: 10.1002/eji.200838659

33. Stabile H, Fionda C, Gismondi A, Santoni A. Role of distinct natural killer cell subsets in anticancer response. Front Immunol. (2017) 8:293. doi: 10.3389/fimmu.2017.00293

34. Richards JO, Chang X, Blaser BW, Caligiuri MA, Zheng P, Liu Y. Tumor growth impedes natural-killer - cell maturation in the bone marrow. Growth (Lakeland) (2006) 108:246-252. doi: 10.1182/blood-2005-11-4535

35. Ikeda H, Old LJ, Schreiber RD. The roles of IFNy in protection against tumor development and cancer immunoediting. Cytokine Growth Factor Rev. (2002) 13:95-109. doi: 10.1016/S1359-6101(01)00038-7

36. Marçais A, Viel S, Grau M, Henry T, Marvel J, Walzer T. Regulation of mouse NK cell development and function by cytokines. Front Immunol. (2013) 4:450. doi: 10.3389/fimmu.2013.00450

37. Lusty E, Poznanski SM, Kwofie K, Mandur TS, Lee DA, Richards CD, et al. IL-18/IL-15/IL-12 synergy induces elevated and prolonged IFN- $\gamma$ production by ex vivo expanded NK cells which is not due to enhanced STAT4 activation. Mol Immunol. (2017) 88:138-147. doi: 10.1016/j.molimm.2017.06.025

38. Boieri M, Ulvmoen A, Sudworth A, Lendrem C, Collin M, Dickinson AM, et al. IL-12, IL-15, and IL-18 pre-activated NK cells target resistant T cell acute lymphoblastic leukemia and delay leukemia development in vivo. Oncoimmunology (2017) 6:1-12. doi: 10.1080/2162402X.2016.1274478

39. Vivier E, Tomasello E, Baratin M, Walzer T, Ugolini S. Functions of natural killer cells. Nat Immunol. (2008) 9:503-10. doi: 10.1038/ni1582

40. Vivier E, Raulet D, Moretta A, Caligiuri M. Innate or adaptive immunity? The example of natural killer cells. Science (2011) 331:44-49. doi: $10.1126 /$ science. 1198687

41. Moretta L, Ferlazzo G, Bottino C, Vitale M, Pende D, Mingari MC, et al. Effector and regulatory events during natural killer-dendritic cell interactions. Immunol Rev. (2006) 214:219-28. doi: 10.1111/j.1600-065X.2006.00450.x

42. Ferlazzo G, Morandi B. Cross-talks between natural killer cells and distinct subsets of dendritic cells. Front Immunol. (2014) 5:159. doi: 10.3389/fimmu.2014.00159

43. Vitale M, Della Chiesa M, Carlomagno S, Pende D, Aricò M, Moretta L, et al. NK-dependent DC maturation is mediated by TNF $\alpha$ and IFN $\gamma$ released upon engagement of the NKp30 triggering receptor. Blood (2005) 106:566-71. doi: 10.1182/blood-2004-10-4035

44. Vidarsson G, Stemerding AM, Stapleton NM, Spliethoff SE, Janssen H, Rebers FE, et al. FcRn: an IgG receptor on phagocytes with a novel role in phagocytosis. Blood (2006) 108:3573-9. doi: 10.1182/blood-2006-05-024539

45. Mantovani A, Cassatella MA, Costantini C, Jaillon S. Neutrophils in the activation and regulation of innate and adaptive immunity. Nat Rev Immunol. (2011) 11:519-31. doi: 10.1038/nri3024

46. Arnoult C, Brachet G, Cadena Castaneda D, Azzopardi N, Passot C, Desvignes $\mathrm{C}$, et al. Crucial role for immune complexes but not FcRn in immunization against anti-TNF- $\alpha$ antibodies after a single injection in mice. J Immunol. (2017) 199:418-24. doi: 10.4049/jimmunol.1601246
47. Dunn GP, Koebel CM, Schreiber RD. Interferons, immunity and cancer immunoediting. Nat Rev Immunol. (2006) 6:836-48. doi: 10.1038/nri1961

48. Jablonska J, Leschner S, Westphal K, Lienenklaus S, Weiss S. Neutrophils responsive to endogenous IFN-beta regulate tumor angiogenesis and growth in a mouse tumor model. J Clin Invest. (2010) 120:1151-64. doi: 10.1172/JCI 37223

49. Andzinski L, Wu CF, Lienenklaus S, Kröger A, Weiss S, Jablonska J. Delayed apoptosis of tumor associated neutrophils in the absence of endogenous IFN-gamma. Int J Cancer (2015) 136:572-83. doi: 10.1002/ijc.2 8957

50. Williams CB, Yeh ES, Soloff AC. Tumor-associated macrophages: unwitting accomplices in breast cancer malignancy. NPJ Breast Cancer (2016) 2:15025. doi: 10.1038/npjbcancer.2015.25

51. Lasnik A, Eaton JW, Mitchell RA, Lamont GJ, Faughn JD, Satoskar A, et al. Control of tumor-associated macrophage alternative activation by macrophage migration inhibitory factor. J Immunol. (2013) 190:2984-93. doi: 10.4049/jimmunol.1201650

52. Kowanetz M, Wu X, Lee J, Tan M, Hagenbeek T, Qu X, et al. Granulocytecolony stimulating factor promotes lung metastasis through mobilization of Ly6G $^{+}$Ly6C ${ }^{+}$granulocytes. Proc Natl Acad Sci USA. (2010) 107:21248-55. doi: $10.1073 /$ pnas. 1015855107

53. Chanmee T, Ontong P, Konno K, Itano N. Tumor-associated macrophages as major players in the tumor microenvironment. Cancers (Basel) (2014) 6:1670-90. doi: 10.3390/cancers6031670

54. Noy R, Pollard JW. Tumor-associated macrophages: from mechanisms to therapy. Immunity (2015) 41:49-61. doi: 10.1016/j.immuni.2014.06.010

55. Coffelt SB, Wellenstein MD, de Visser KE. Neutrophils in cancer: neutral no more. Nat Rev Cancer (2016) 16:431-46. doi: 10.1038/nrc.2016.52

56. Sun JC, Lanier LL. NK cell development, homeostasis and function: parallels with $\mathrm{CD}^{+}$T cells. Nat Rev Immunol. (2011) 11:645-57. doi: 10.1038/nr i3044

57. Yu J, Freud AG, Caligiuri MA. Location and cellular stages of natural killer cell development. Trends Immunol. (2013) 34:573-82. doi: 10.1016/j.it.2013.07.005

Conflict of Interest Statement: The authors declare that the research was conducted in the absence of any commercial or financial relationships that could be construed as a potential conflict of interest.

Copyright (c) 2018 Castaneda, Dhommée, Baranek, Dalloneau, Lajoie, Valayer, Arnoult, Demattéi, Fouquenet, Parent, Heuzé-Vourc'h and Gouilleux-Gruart. This is an open-access article distributed under the terms of the Creative Commons Attribution License (CC BY). The use, distribution or reproduction in other forums is permitted, provided the original author(s) and the copyright owner(s) are credited and that the original publication in this journal is cited, in accordance with accepted academic practice. No use, distribution or reproduction is permitted which does not comply with these terms. 